\title{
Epistasis for Vegetative and Reproductive Traits in Peanut
}

\author{
Hari D. Upadhyaya* and Shyam N. Nigam
}

\begin{abstract}
Most genetic models assume absence of epistasis while estimating components of genetic variation. However, epistasis when present introduces bias. These biased estimates affect the progress in a breeding program since they influence the choice of breeding methodology. The objectives of this study were to determine the significance of epistasis in the inheritance of pod yield and related traits in 15 peanut (Arachis hypogaea L.) cultigens, and to estimate the additive and dominance variances for the traits not influenced by epistasis. Two cultigens and their $F_{1}$ hybrid were each crossed to 15 cultigens from 13 countries, representing three botanical groups. The experiment was conducted in the 1992-1993 post-rainy and 1993 rainy environments at the ICRISAT Asia Center, Patancheru, India. The deviations were analyzed to detect epistasis of 11 traits. Epistasis affected the expression of eight traits in both environments. Environments interacted more strongly with epistatic gene actions than with additive or dominance gene actions. Expression of epistasis was influenced by genotypes and environments, indicating the need for more genotypes and environments for effective detection of epistasis. Evidence for additive genetic variance and lower levels of partial dominance for canopy breadth and additive and dominance variances and complete dominance for shelling outturn was obtained in the post-rainy environment.
\end{abstract}

$\mathrm{M}$ ANY TRAITS of economic importance in peanut, a self pollinated annual legume crop, are quantitatively inherited. The exploitation of genetic variability

Genetic Enhancement Division, ICRISAT Asia Center, Patancheru, 502 324, Andhra Pradesh, India. ICRISAT J.A. no. 1981. Received 24 Oct. 1996. *Corresponding author (H.UPADHYAYA@ CGNET.COM).

Published in Crop Sci. 38:44-49 (1998). (additive variation) of these traits through hybridization, inbreeding, and selection is the primary focus of most peanut improvement programs. A good knowledge of the genetic systems controlling expression of these characters facilitates the choice of the most efficient breeding and selection procedure.

In addition to additive and dominance variation (Parker et al., 1970; Wynne et al., 1970; Upadhyaya et al., 1992), it has been suggested that epistasis may also be involved in the inheritance of many quantitative characters in peanut (Hammons, 1973; Wynne, 1976). But the information available on nonallelic interactions for quantitative traits in peanut is very limited. Halward and Wynne (1991) reported significant additive $\times$ dominance epistasis for pod yield and pod length, and additive $X$ additive epistasis for seed number in one of their two crosses. However, Sandhu and Khera (1976) observed all three types of epistases (additive $\times$ additive, additive $\times$ dominance, and dominance $\times$ dominance) to be of significance for pod yield in one cross and for 100-seed weight in another cross at only one of two locations. Isleib et al. (1978) reported additive $\times$ additive type epistasis for pod yield and pod length. In spite of the limited scope of exploitation of nonallelic interactions in peanut, the information on nonallelic interactions would be of value to peanut breeders. While variation due to dominance effects and their interactions cannot be exploited effectively in peanut, additive $\times$ additive epistatic variation is potentially useful, as it can be fixed in homozygous cultivars. This is particularly important in view of increased use of exotic germplasm in peanut breeding programs to broaden the genetic 
base. As genetic diversity in a breeding program increases, the roles of dominance and epistasis may increase significantly (Halward and Wynne, 1991).

The objectives of the present experiment were to study the importance of epistasis and to determine additive and dominance variances for pod yield and other vegetative and reproductive traits in peanut.

\section{MATERIALS AND METHODS}

The materials for the experiment were developed at the International Crops Research Institute for the Semi-Arid Tropics, Asia Center (IAC), Patancheru, Andhra Pradesh, India. Two cultigens, Chico (Bailey and Hammons, 1975) and ICGV 86300 (hereafter referred to as $L_{1}$ and $L_{2}$ ), were crossed to produce the $\mathrm{F}_{1}$ hybrid (designated as $\mathrm{L}_{3}$ ) in the 1991-1992 post-rainy environment. Chico is a short-duration spanish (subsp. fastigiata Waldron var. vulgaris Harz) germplasm line, selected from PI 268661 and released as germplasm in USA. ICGV 86300 is a high-yielding, medium-duration virginia (subsp. hypogaea Krap. \& Rig. var. hypogaea Gregory et al.) breeding line, developed at IAC, from a cross between ICGV 87121 (Nigam et al., 1992) and $C 166$. The three testers $\left(L_{1}\right.$, $L_{2}$, and $\left.L_{3}\right)$ were crossed in the 1992 rainy environment with 15 cultigens from diverse germplasm sources. These cultigens consisted of five each of spanish, valencia (subsp. fastigiata Waldron var. fastigiata Gregory et al.), and virginia botanical types. They originated from 13 countries (Table 1 ). The experiment consisted of 17 cultigens ( $L_{1}$ and $L_{2}$ testers and 15 cultigens), 31 single crosses including $L_{3}$ tester, and 15 threeway crosses.

The experiment was planted in the 1992-1993 post-rainy and 1993 rainy environments in alfisols- Patancheru Soil Series (Udic Rhodustolf) in a randomized complete block design with three replications. Each treatment consisted of a $3.5-\mathrm{m}$ row on a ridge. The distance between rows was $60 \mathrm{~cm}$ and between plants within a row $15 \mathrm{~cm}$. Care was taken to ensure uniform depth of planting. Seeds were treated with ethrel (2chloroethylphosphonic acid) before sowing to overcome the possible effects of postharvest seed dormancy of virginia genotypes in their cross populations. The experiments received 60 $\mathrm{kg} \mathrm{P}_{2} \mathrm{O}_{5} \mathrm{ha}^{-1}, 400 \mathrm{~kg}_{\text {gypsum ha }}{ }^{-1}$, full irrigation (10 irrigations in post-rainy and four in rainy environment, each irrigation with $5 \mathrm{~cm}$ of water) and protection against diseases, insect pests, and weeds. In each treatment ten competitive plants were selected randomly to record observations on plant height $(\mathrm{cm})$, canopy breadth $(\mathrm{cm})$, number of primary branches and mature pods, length and breadth of 20 mature pods $(\mathrm{cm})$, length and breadth of 20 mature seeds $(\mathrm{cm})$, weight of 100 mature seeds $(\mathrm{g})$, pod yield $(\mathrm{g})$, and shelling outturn (\%). The statistical analyses were based on plot means.

The method for detecting epistasis was triple test cross (Kearsey and Jinks, 1968) as modified by Ketata et al. (1976). In this method a set of cultigens is crossed with testers $\mathrm{L}_{1}, \mathrm{~L}_{2}$, and $L_{3}$, where $L_{3}$ is the $F_{1}$ between $L_{1}$ and $L_{2}$. In the analysis of variance (ANOVA), presence of epistasis is indicated, if the mean squares for deviations, $L_{i j}+L_{2 j}-2 L_{3 j}$, are significantly greater than the pooled error, as evaluated by an $F$ test. However, when all the deviations are of the same sign and of comparable magnitude, the $F$ test in ANOVA would fail to detect the epistasis even though it may be present. To cope with this situation, a $t$ test was used on mean deviations to detect the significance of epistasis. Further, the sum of squares (SS) due to epistasis was partitioned into SS due to $i$ (additive $\times$ additive) type of epistasis and SS due to $j+1$ (additive $\times$ dominance + dominance $\times$ dominance) types of
Table 1. Cultigens used in the study to detect epistasis.

\begin{tabular}{|c|c|c|c|}
\hline Germplasm & $\begin{array}{c}\text { Country of } \\
\text { origin }\end{array}$ & Synonym & $\begin{array}{c}\text { Botanical } \\
\text { type }\end{array}$ \\
\hline CG 5136 & Gambia & Basse, PI 229552 & Spanish \\
\hline & Nig & RG 105, Kano & panish \\
\hline 79 & India & VRR 467 & panish \\
\hline 22 & Uganda & Uganda Erect, PI 268 & Spanish \\
\hline 475 & Paraguay & RCM 508, PI 262002 & Spanish \\
\hline CG 1638 & Brazil & SH 128, PI 1 & Valencia \\
\hline ICG 6030 & Gambia & Gambia Bunch, PI 268707 & Valencia \\
\hline ICGV 6393 & Zimb & Makanga Bu & Valenci \\
\hline ICG 6473 & Mozambique & Masambika & Valenci \\
\hline ICG 11474 & Argentina & RCM 454 & Valencia \\
\hline ICG 6163 & Ghana & Kusai, PI 240576 & Virginia \\
\hline ICG 6207 & Bolivi & RCM 439, PI & Virginia \\
\hline ICG 4329 & Tanzania & Kongwa Runner & Virginia \\
\hline & Bolivia & V 108 & Virginia \\
\hline & Sudan & Beladi Runner & Virginia \\
\hline
\end{tabular}

epistasis (Jinks and Perkins, 1970). In the ANOVA, significance of each of the three types of epistasis (total, $i$, and $j+$ 1) was tested against their respective interactions with blocks. However, before testing the significance of individual epistasis, the homogeneity of interactions was tested. As there were only two interaction variances $(i \times$ block $)$ and $[(j+1) \times$ block], the homogeneity was tested by an $F$ test. In cases where the $F$ value was nonsignificant, thus indicating homogeneity of interaction variances, the $i$ and $j+1$ types of epistasis were also tested against pooled error (total epistasis $\times$ block).

For those characters in which epistasis was not detected an additive-dominance model was fitted (Kearsey and Jinks 1968; Jinks et al., 1969). The additive $(D)$ and dominance $\left(H_{1}\right)$ components of variation were estimated from the mean squares due to sums and differences within an environment, respectively. The direction of dominance was determined by the correlation coefficient between the corresponding sums $\left(L_{1 j}+L_{2 j}\right)$ and the differences $\left(L_{1 j}-L_{2 j}\right)$ of lines. Average degree of dominance was calculated as $\left(H_{1} / D\right)^{1 / 2}$.

The genotype $\times$ environment interaction in the triple test cross data was detected following the analysis suggested by Perkins and Jinks (1971). For traits where interactions of deviations $\left(L_{j j}+L_{2 j}-2 L_{3 j}\right)$, sums $\left(L_{j j}+L_{2 j}\right)$ or differences $\left(L_{j j}-L_{2 j}\right)$ with the environments were significant, the data were analyzed separately for both the environments.

\section{RESULTS AND DISCUSSION}

Total epistasis was detected for seven traits each in the 1992-1993 post-rainy and 1993 rainy environments (Table 2). Four traits (plant height, pod length, 100seed weight, and pod yield) exhibited total epistasis in both environments. The $i$ type epistasis, which is fixable, was significant for seven traits in the 1992-1993 postrainy environment. Three traits (number of mature pods and pod length and breadth) were significant in the post-rainy and rainy environments. The $j+1$ type epistasis was significant for five traits in the post-rainy and for seven traits in the rainy environment. Plant height and 100 -seed weight were common in both the environments. Considering all types of epistasis (total, $i$, and $j+1$ ) and both $\mathrm{F}$ and $t$ tests (Tables 2 and 3) the importance of epistasis was detected for eight traits (plant height, number of mature pods, pod length and breadth, seed length and breadth, 100 -seed weight, and pod yield) in both environments. Some of these results are in agreement with those obtained by Sandhu and Khera (1976) and Isleib et al. (1978). The former re- 
Table 2. Mean squares for epistatic, additive, and dominance components for different traits (within environment) in peanut in the 1992-1993 post-rainy (PR) and 1993 rainy (R) environments.

\begin{tabular}{|c|c|c|c|c|c|c|c|c|}
\hline Source & df & $\begin{array}{c}\text { Environ- } \\
\text { ment }\end{array}$ & $\begin{array}{c}\text { Plant } \\
\text { height } \\
\text { (cm) }\end{array}$ & $\begin{array}{l}\text { Canopy } \\
\text { breadth } \\
\text { (cm) }\end{array}$ & $\begin{array}{l}\text { Number of } \\
\text { primary } \\
\text { branches }\end{array}$ & $\begin{array}{c}\text { Number of } \\
\text { mature } \\
\text { pods }\end{array}$ & $\begin{array}{l}\text { Pod } \\
\text { length } \\
\text { (cm) }\end{array}$ & $\begin{array}{c}\text { Pod } \\
\text { breadth } \\
\text { (cm) }\end{array}$ \\
\hline \multicolumn{9}{|l|}{ Epistatic component } \\
\hline Total epistasis & 15 & $\underset{\mathbf{R}}{\mathbf{P R}}$ & $\begin{array}{r}36.02 * \\
202.03 *\end{array}$ & $\begin{array}{c}84.44 \\
74811 *\end{array}$ & $35.44^{*}$ & $\begin{array}{l}908.87 \\
270.00 *\end{array}$ & $\begin{array}{l}\text { 282.22* } \\
35550 * *\end{array}$ & 22.18 \\
\hline \multirow[t]{2}{*}{ Error } & 30 & PR & 17.02 & 76.51 & $\begin{array}{l}14.04 \\
13.24\end{array}$ & 681.87 & 120.14 & 16.80 \\
\hline & & $\mathbf{R}$ & 83.27 & 298.91 & 21.91 & 104.09 & 91.13 & 55.73 \\
\hline \multirow[t]{2}{*}{$i$ type epistasis } & 1 & $\mathbf{P R}$ & $\mathbf{2 4 . 2 0}$ & 64.80 & $125.00^{* *}$ & $7605.00^{*}$ & $1441.60 *$ & $79.20 *$ \\
\hline & & $\mathbf{R}$ & 309.42 & 827.76 & 0.80 & $989.36^{* *}$ & $806.45^{* *}$ & $253.95 * *$ \\
\hline \multirow[t]{2}{*}{ Error } & 2 & $\mathbf{P R}$ & 42.47 & 12.87 & 32.27 & 146.07 & 34.51 & 7.42 \\
\hline & & $\mathbf{R}$ & 187.62 & 292.16 & 33.07 & 187.29 & 198.89 & 38.43 \\
\hline \multirow[t]{2}{*}{$j+l$ type epistasis } & 14 & $\mathbf{P R}$ & $36.87^{*}$ & $\mathbf{8 5 . 8 5}$ & $29.05 *$ & 430.57 & 199.40 & 18.11 \\
\hline & & $\mathbf{R}$ & $195.33 *$ & $742.42 *$ & 14.99 & $228.36 *$ & 323.29** & $279.26 * *$ \\
\hline \multirow[t]{2}{*}{ Error } & 28 & $\mathbf{P R}$ & 15.20 & 81.06 & 11.89 & 720.14 & 126.26 & 17.47 \\
\hline & & $\mathbf{R}$ & 75.81 & 299.39 & 21.11 & 98.15 & 83.43 & 56.97 \\
\hline \multicolumn{9}{|l|}{ Additive component } \\
\hline \multirow[t]{2}{*}{ Sums $\left(L_{1 j}+L_{2 j}\right)$} & 14 & PR & $22.69 * *$ & $494.64 * *$ & $24.28 * *$ & $762.50 * *$ & $335.34 * *$ & $22.99 * *$ \\
\hline & & $\mathbf{R}$ & $116.18 * *$ & $1168.90^{* *}$ & 7.08 & $189.61^{* *}$ & $264.29 * *$ & $120.43 * *$ \\
\hline \multirow[t]{2}{*}{ Error } & 28 & $\mathbf{P R}$ & 8.04 & 34.74 & 4.39 & 235.10 & 23.62 & 2.36 \\
\hline & & $\mathbf{R}$ & 32.17 & 129.30 & 6.12 & $\mathbf{3 8 . 3 4}$ & 39.16 & 6.86 \\
\hline \multicolumn{9}{|l|}{ Dominance component } \\
\hline \multirow[t]{4}{*}{ Differences $\left(L_{1 j}+L_{2 j}\right)$} & 14 & PR & 9.51 & 50.70 & 11.59 & 188.90 & 41.50 & 6.39 \\
\hline & & $\mathbf{R}$ & 38.13 & $321.40 *$ & 8.26 & 85.59 & $110.67^{*}$ & $113.45^{*}$ \\
\hline & 28 & $\mathbf{P R}$ & 5.01 & 30.81 & 7.66 & 175.60 & 39.29 & 5.09 \\
\hline & & $\mathbf{R}$ & 24.23 & 117.50 & 6.29 & 53.99 & 41.04 & 9.17 \\
\hline Source & df & $\begin{array}{c}\text { Environ- } \\
\text { ment }\end{array}$ & $\begin{array}{c}\text { Seed } \\
\text { length } \\
(\mathrm{cm})\end{array}$ & $\begin{array}{c}\text { Seed } \\
\text { breadth } \\
\text { (cm) }\end{array}$ & $\begin{array}{l}\text { 100-seed } \\
\text { weight } \\
\text { (g) }\end{array}$ & $\begin{array}{c}\text { Pod yield } \\
\text { (g) }\end{array}$ & $\begin{array}{c}\text { Shelling } \\
\text { outturn } \\
(\%)\end{array}$ & \\
\hline \multicolumn{9}{|l|}{ Epistatic component } \\
\hline \multirow[t]{2}{*}{ Total epistasis } & 15 & PR & $117.77 * *$ & $61.02 * *$ & $276.87^{* *}$ & $1995.25^{* *}$ & 132.67 & \\
\hline & & $\mathbf{R}$ & 8.31 & 7.27 & $297.60 *$ & 203.22* & 641.18 & \\
\hline \multirow[t]{2}{*}{ Error } & 30 & PR & 10.03 & $\mathbf{3 . 3 7}$ & 80.10 & 721.98 & 77.30 & \\
\hline & & $\mathbf{R}$ & 9.13 & 4.34 & 113.71 & 88.79 & 429.84 & \\
\hline \multirow[t]{2}{*}{$i$ type epistasis } & 1 & $\mathbf{P R}$ & 2.79 & $70.44^{* *}$ & $642.98 * *$ & $16665.70 * *$ & 0.80 & \\
\hline & & $\mathbf{R}$ & 0.70 & 0.29 & 235.76 & 325.89 & 1560.56 & \\
\hline \multirow[t]{2}{*}{ Error } & 2 & $\mathbf{P R}$ & 3.67 & 4.07 & 78.10 & 558.65 & $\mathbf{7 2 . 8 0}$ & \\
\hline & & $\mathbf{R}$ & 25.01 & 2.91 & 219.03 & 162.97 & 1310.82 & \\
\hline \multirow{4}{*}{$\begin{array}{l}j+l \text { type } \\
\text { epistasis } \\
\text { Error }\end{array}$} & 14 & $\mathbf{P R}$ & $125.98^{* *}$ & $60.35 * *$ & $250.72 * *$ & 947.36 & 142.09 & \\
\hline & & $\mathbf{R}$ & 8.86 & 7.77 & 302.02* & $194.46^{*}$ & 575.51 & \\
\hline & 28 & $\mathbf{P R}$ & 10.48 & 3.31 & 80.24 & 733.64 & 77.66 & \\
\hline & & $\mathbf{R}$ & 8.00 & 4.44 & 106.18 & 83.49 & 366.92 & \\
\hline \multicolumn{9}{|l|}{ Additive component } \\
\hline Sums $\left(L_{1 j}+L_{2 j}\right)$ & 14 & $\mathbf{P R}$ & $20.25 * *$ & 2.08 & $152.01 * *$ & $1492.20^{* *}$ & $86.49 *$ & \\
\hline & & $\mathbf{R}$ & $10.51 *$ & $4.92 *$ & $236.72 * *$ & $127.79 * *$ & 143.70 & \\
\hline Error & 28 & PR & 6.24 & 1.51 & 24.63 & 292.50 & 32.60 & \\
\hline & & $\mathbf{R}$ & 4.75 & 1.93 & 41.07 & 28.21 & 124.20 & \\
\hline Dominance component & & & & & & & & \\
\hline Differences $\left(L_{1 j}+L_{2 j}\right)$ & 14 & PR & 11.14 & 1.95 & $152.28 * *$ & 226.00 & $71.37 * *$ & \\
\hline & & $\mathbf{R}$ & 5.45 & 2.18 & $155.54 * *$ & 49.29 & 100.56 & \\
\hline Error & 28 & $\mathbf{P R}$ & 7.11 & 1.77 & 38.81 & 195.70 & 18.52 & \\
\hline & & $\mathbf{R}$ & 3.58 & 1.56 & 49.03 & 44.13 & 94.23 & \\
\hline
\end{tabular}

*,** Significant at 0.05 and 0.01 levels of probability, respectively.

ported significant $i, j$, and $l$ epistases for pod yield and 100 -seed weight, and the latter found significant $i$ epistasis for pod yield and pod length. Halward and Wynne (1991) also observed significant epistasis ( $j$ type) for pod yield and pod length.

The combined analysis of variance indicated significant total epistasis $\times$ environment interactions for all the traits (Table 4). Epistatic effects in the present study were more unstable as they interacted significantly and strongly with environment as compared with additive and dominance effects. Perkins and Jinks (1971) in Nicotiana rustica L., Yermanos and Allard (1961) in flax (Linum usitatissimum L.), Gamble (1962) in maize, and Sandhu and Khera (1976) in peanut reported similar instability of epistatic gene effects. The environment interactions depend on the number of genes involved in the inheritance, and as the number increases the opportunities for environmental influence become greater (Gamble, 1962). This could be one of the possible reason for strong epistasis $x$ environment interaction in this and other studies. The $i$ type epistasis $\times$ environment interactions were significant for all the traits except canopy breadth, pod breadth, seed length, and 100-seed weight. The $j+l$ type epistasis $\times$ environment interactions were significant for all the traits except primary branches and number of mature pods. For pod length, pod yield, and shelling outturn, all types of epistases and environments interactions were significant. The $i$ type epistasis interacted more strongly with environments than the other two types. This indicated that $i$ 
Table 3. Epistatic deviations as detected by $t$ test for traits exhibiting significant differences among cultigens tested in the 1992-1993 post-rainy (PR) and 1993 rainy (R) environments.

\begin{tabular}{|c|c|c|c|c|c|c|c|c|c|c|}
\hline \multirow[b]{2}{*}{ Cultigen } & \multicolumn{2}{|c|}{$\begin{array}{c}\text { Plant height } \\
\text { (cm) }\end{array}$} & \multirow{2}{*}{$\begin{array}{c}\begin{array}{c}\text { Canopy } \\
\text { breadth } \\
\text { (cm) }\end{array} \\
\mathbf{R} \\
\end{array}$} & \multirow{2}{*}{$\begin{array}{c}\text { Number of } \\
\text { primary } \\
\text { branches }\end{array}$} & \multicolumn{2}{|c|}{$\begin{array}{l}\text { Number of mature } \\
\text { pods }\end{array}$} & \multicolumn{2}{|c|}{ Pod length $(\mathrm{cm})$} & \multicolumn{2}{|c|}{ Pod breadth $(\mathrm{cm})$} \\
\hline & $\mathbf{P R}$ & $\mathbf{R}$ & & & $\mathbf{P R}$ & $\mathbf{R}$ & $\mathbf{P R}$ & $\mathbf{R}$ & $\mathbf{P R}$ & $\mathbf{R}$ \\
\hline $\begin{array}{l}\text { ICG } 5136 \\
\text { ICG } 8480 \\
\text { ICG } 9579 \\
\text { ICG } 10522 \\
\text { ICG } 11475\end{array}$ & $\begin{array}{r}\mathbf{0 . 0 0} \\
\mathbf{0 . 6 7} \\
-\mathbf{1 . 0 0} \\
-\mathbf{3 . 3 3} \\
\mathbf{0 . 0 0}\end{array}$ & $\begin{array}{r}-\mathbf{8 . 3 3 *} \\
\mathbf{8 . 0 0} \\
-\mathbf{1 4 . 3 3} \\
\mathbf{0 . 0 0} \\
-\mathbf{1 1 . 0 0 *}\end{array}$ & $\begin{array}{c}\mathbf{0 . 3 3} \\
22.00 * * \\
-15.67 \\
10.33 \\
5.00\end{array}$ & $\begin{array}{l}0.00 \\
4.67^{* *} \\
4.33 \\
2.33 \\
1.33\end{array}$ & $\begin{array}{c}22.33^{* *} \\
32.67 * * \\
-1.33 \\
18.00 \\
16.33\end{array}$ & $\begin{array}{r}\mathbf{5 . 3 3 * *} \\
\mathbf{8 . 6 7 *} \\
8.67 \\
2.67 \\
13.33\end{array}$ & \begin{tabular}{r|}
-8.33 \\
5.53 \\
8.87 \\
7.03 \\
-4.60
\end{tabular} & $\begin{array}{c}-22.93^{* *} \\
-\mathbf{8 . 1 7} \\
-20.43 \\
-7.50 \\
-\mathbf{1 . 8 0}\end{array}$ & $\begin{array}{r}-\mathbf{3 . 2 3} \\
\mathbf{1 . 4 7} \\
\mathbf{3 . 2 3} \\
-\mathbf{0 . 0 3} \\
-\mathbf{1 . 7 7}\end{array}$ & $\begin{array}{r}-2.07 \\
1.93 \\
1.03 \\
-1.90 \\
-7.47\end{array}$ \\
\hline $\begin{array}{l}\text { ICG } 1638 \\
\text { ICG } 6030 \\
\text { ICG } 6393 \\
\text { ICG } 6473 \\
\text { ICG } 11474\end{array}$ & $\begin{array}{c}-0.33 \\
-2.33 \\
-4.33 * * \\
-10.33 \\
-0.67\end{array}$ & $\begin{array}{c}10.00^{*} \\
1.67 \\
-10.33^{* *} \\
5.67 \\
7.67\end{array}$ & $\begin{array}{c}31.67 \\
11.67 \\
-14.67 * \\
13.33 \\
21.67 * *\end{array}$ & $\begin{array}{l}4.33^{* *} \\
4.67 \\
-0.67 \\
6.00^{* *} \\
1.00\end{array}$ & \begin{tabular}{|r|}
12.67 \\
4.00 \\
4.67 \\
12.33 \\
11.00
\end{tabular} & \begin{tabular}{|r|}
14.67 \\
-3.67 \\
7.33 \\
9.00 \\
10.67
\end{tabular} & $\begin{array}{c}-4.90 \\
17.73 \\
-2.17 \\
8.97 \\
8.63 * *\end{array}$ & $\begin{array}{r}-\mathbf{4 . 0 3 *} \\
-\mathbf{0 . 1 7} \\
\mathbf{7 . 3 3} \\
-\mathbf{3 . 9 3} \\
\mathbf{8 . 9 7}\end{array}$ & $\begin{array}{c}-\mathbf{0 . 1 0} \\
\mathbf{3 . 7 3} \\
-\mathbf{1 . 4 8} \\
\mathbf{3 . 1 3} \\
\mathbf{3 . 4 7 ^ { * }}\end{array}$ & $\begin{array}{l}2.93 \\
2.00 \\
2.67^{*} \\
1.60 \\
3.23\end{array}$ \\
\hline $\begin{array}{l}\text { ICG } 6163 \\
\text { ICG } 6207 \\
\text { ICG } 6289 \\
\text { ICG } 4329 \\
\text { ICG } 6685\end{array}$ & $\begin{array}{r}-\mathbf{1 . 0 0} \\
\mathbf{3 . 6 7} \\
\mathbf{2 . 3 3} \\
\mathbf{3 . 0 0} \\
\mathbf{2 . 6 7}\end{array}$ & $\begin{array}{c}-0.33 \\
-10.00 \\
-10.00 * \\
-0.67 \\
-7.33\end{array}$ & $\begin{array}{r}-28.00 \\
7.67 \\
4.00 \\
-4.33 \\
-0.67\end{array}$ & $\begin{array}{c}-5.33 * * \\
0.33 \\
\mathbf{4 . 3 3} \\
-\mathbf{2 . 0 0} \\
-0.33\end{array}$ & $\begin{array}{r}-11.00 \\
2.00 \\
20.00 \\
31.67 \\
19.67\end{array}$ & $\begin{array}{c}-14.67 \\
1.33 \\
14.67^{*} \\
3.00^{* *} \\
-10.67\end{array}$ & $\begin{array}{c}6.23 \\
0.77 \\
16.10^{*} \\
7.43 \\
17.60\end{array}$ & $\begin{array}{r}-14.50 \\
-10.17 \\
13.53 \\
4.90 \\
-4.60\end{array}$ & $\begin{array}{l}\mathbf{5 . 0 3} \\
\mathbf{0 . 2 0} \\
\mathbf{3 . 4 3} * * \\
-\mathbf{0 . 3 3} \\
\mathbf{3 . 1 0} * *\end{array}$ & $\begin{array}{c}-6.80 \\
-0.10 \\
12.07 \\
32.53 * * \\
-6.03 * *\end{array}$ \\
\hline & \multicolumn{2}{|c|}{ Seed length $(\mathrm{cm})$} & \multicolumn{2}{|c|}{ Seed breadth $(\mathrm{cm})$} & \multicolumn{2}{|c|}{ 100-seed weight $(\mathrm{g})$} & \multicolumn{2}{|c|}{ Pod yield $(\mathrm{g})$} & \multicolumn{2}{|c|}{ Shelling outturn $(\%)$} \\
\hline Cultigen & PR & $\mathbf{R}$ & PR & $\mathbf{R}$ & PR & $\mathbf{R}$ & PR & $\mathbf{R}$ & & \\
\hline $\begin{array}{l}\text { ICG } 5136 \\
\text { ICG } 8480 \\
\text { ICG } 9579 \\
\text { ICG } 10522 \\
\text { ICG } 11475\end{array}$ & $\begin{array}{c}-\mathbf{1 . 2 3} \\
\mathbf{2 . 5 3} \\
\mathbf{1 . 5 0} \\
\mathbf{2 . 7 7} \\
-\mathbf{0 . 8 0}\end{array}$ & $\begin{array}{l}\mathbf{0 . 3 0} \\
2.17 * * \\
-1.37 \\
-\mathbf{0 . 9 7} \\
-\mathbf{0 . 0 7}\end{array}$ & $\begin{array}{r}-\mathbf{1 . 3 7} \\
-\mathbf{0 . 7 0} \\
-\mathbf{2 . 3 7} \\
\mathbf{0 . 3 3} \\
-\mathbf{0 . 7 7}\end{array}$ & $\begin{array}{r}-0.23 \\
0.43 \\
1.23 \\
0.53 * \\
-1.83\end{array}$ & $\begin{array}{c}9.63 \\
9.66 * * \\
-5.53 \\
17.60 \\
-2.23\end{array}$ & $\begin{array}{r}\mathbf{1 0 . 0 3} \\
\mathbf{5 . 8 0} \\
-\mathbf{0 . 0 7} \\
-\mathbf{0 . 8 0} \\
\mathbf{8 . 0 7}\end{array}$ & $\begin{array}{c}18.00 \\
38.63 * * \\
7.10 \\
28.57 * * \\
4.43\end{array}$ & \begin{tabular}{r|}
2.77 \\
6.17 \\
1.37 \\
2.43 \\
11.83
\end{tabular} & $\begin{array}{r}-1 \\
- \\
-1\end{array}$ & \\
\hline $\begin{array}{l}\text { ICG } 1638 \\
\text { ICG } 6030 \\
\text { ICG } 6393 \\
\text { ICG } 6473 \\
\text { ICG } 11474\end{array}$ & $\begin{array}{r}0.57 \\
2.77 \\
-1.90 \\
1.47 \\
-22.60 *\end{array}$ & $\begin{array}{r}\mathbf{0 . 4 3} \\
-0.23 \\
\mathbf{1 . 1 3} \\
\mathbf{0 . 1 7} \\
\mathbf{3 . 8 7} *\end{array}$ & $\begin{array}{c}0.47 \\
-0.40 \\
-0.57 \\
0.47 \\
-16.60 * *\end{array}$ & $\begin{array}{r}0.50 \\
-0.50 \\
1.27 \\
-\mathbf{1 . 1 3} \\
\mathbf{1 . 3 3}\end{array}$ & $\begin{array}{r}\mathbf{5 . 9 3} \\
\mathbf{5 . 9 3} \\
-\mathbf{7 . 3 0} \\
-\mathbf{2 . 1 0} \\
-\mathbf{0 . 5 3}\end{array}$ & $\begin{array}{c}-7.87 \\
9.57 * \\
-5.93 \\
14.93 \\
17.93 * *\end{array}$ & \begin{tabular}{|r|r|}
6.73 \\
12.10 \\
7.53 \\
25.57 \\
11.47
\end{tabular} & $\begin{array}{r}10.37 \\
-2.47 \\
15.83 \\
-\mathbf{3 . 5 0} \\
\mathbf{6 . 0 3}\end{array}$ & & \\
\hline $\begin{array}{l}\text { ICG } 6163 \\
\text { ICG } 6207 \\
\text { ICG } 6289 \\
\text { ICG } 4329 \\
\text { ICG } 6685\end{array}$ & $\begin{array}{l}0.07 \\
2.03 \\
1.57 \\
6.10 \\
1.43\end{array}$ & $\begin{array}{r}-\mathbf{3 . 0 7} \\
\mathbf{0 . 0 3} \\
-\mathbf{0 . 7 7} \\
-\mathbf{1 . 5 0} \\
-\mathbf{2 . 2 7} *\end{array}$ & $\begin{array}{r}-0.57 \\
-0.53 \\
-\mathbf{1 . 5 0} \\
\mathbf{3 . 8 7} \\
\mathbf{1 . 4 7}\end{array}$ & $\begin{array}{r}-0.03 \\
0.80 \\
1.60 \\
-0.43 \\
-4.73\end{array}$ & $\begin{array}{r}14.37 \\
6.67 \\
-13.23 * \\
0.60 \\
17.30\end{array}$ & $\begin{array}{c}-17.63 * * \\
-9.97 \\
9.97 \\
4.90 \\
-4.60\end{array}$ & $\begin{array}{c}11.70 \\
-14.93 * * \\
50.40 * * \\
44.53 \\
36.83\end{array}$ & $\begin{array}{c}-12.30 \\
-5.07 \\
13.77 * * \\
-0.30 \\
-6.57\end{array}$ & & \\
\hline
\end{tabular}

*,** Significant at 0.05 and 0.01 levels of probability, respectively.

type epistatic gene effects controlling these traits were more sensitive to the environmental differences. Perkins and Jinks (1971) also made similar observations in $N$. rustica.

The procedure used in this study provides for a test for epistasis that is valid regardless of gene frequencies, degree of inbreeding, and linkage relationships (Ketata et al., 1976). Because epistasis was detected for different traits, the estimates of additive and dominance components of variance for these traits would have been biased had they been estimated by the procedures assuming no epistasis. Further, the presence of epistasis has important implications in a plant breeding program. The $i$ type of epistasis which is fixable in the homozygous state can be exploited in a breeding program of self pollinated crops such as peanut.

Overall the three botanical (spanish, valencia, and virginia) types contributed to an equal number of cases of significant epistatic deviations (Table 3). However, within the three groups, the contribution of different cultigens varied greatly. Thus, in the spanish group ICG 8480 contributed in eight cases of significance whereas ICG 9579 did not contribute to any. As reported in other crops (Burton, 1968; Malhotra and Singh, 1989), the manifestation of epistais in peanut is genotype dependent. This reinforces the need to include several cultigens in studies designed to detect epistasis (Ketata et al., 1976). Also, both $\mathrm{F}$ and $t$ tests should be employed to detect the presence of epistasis. This is required because in some cases an $F$ test may fail to detect epistais. Such situations occurred for shelling outturn and seed length and seed breadth in the 1993 rainy environment where the epistasis was detected by $t$ test (Tables 2 and 3 ).

The testers (Chico and ICGV 86300), used in this study, belong to different botanical groups and proved efficient in detecting epistasis for most traits (Tables 2 and 3). Use of two or more pairs of testers could have improved the possibility of detection of epistasis particularly for the traits for which it was not detected in this study. Alternatively, use of more locations would have helped in improving detection of epistasis. However, the difficulty in obtaining sufficient hybrid seed in peanut restricts the use of more tester pairs or conducting such experiments at more locations.

The analysis of variance for sums showed that mean squares due to sums were significant for all the traits except seed breadth in the 1992-1993 post-rainy environment and for all traits except primary branches and shelling outturn in the 1993 rainy environment (Table 2 ). The sums $\times$ environment interactions were significant for all traits except seed length and shelling outturn 
Table 4. Mean squares for epistatic, additive, and dominance components and their interactions with environments for different traits in peanut.

\begin{tabular}{|c|c|c|c|c|c|c|c|}
\hline Source & df & $\begin{array}{l}\text { Plant } \\
\text { height } \\
\text { (cm) }\end{array}$ & $\begin{array}{c}\text { Canopy } \\
\text { breadth } \\
\text { (cm) }\end{array}$ & $\begin{array}{c}\text { Number of } \\
\text { primary } \\
\text { branches }\end{array}$ & $\begin{array}{c}\text { Number of } \\
\text { mature } \\
\text { pods }\end{array}$ & $\begin{array}{c}\text { Pod } \\
\text { length } \\
\text { (cm) }\end{array}$ & $\begin{array}{c}\text { Pod } \\
\text { breadth } \\
\text { (cm) }\end{array}$ \\
\hline \multicolumn{8}{|l|}{ Epistatic component } \\
\hline Total epistasis & 15 & 288.94 & 1424.33 & $107.51 *$ & 2172.19 & 976.64 & 443.06 \\
\hline$i$ type epistasis & 1 & 506.69 & $1355.76 * *$ & 105.80 & 14080.36 & 91.59 & $616.79 * *$ \\
\hline$j+l$ type epistasis & 14 & 273.39 & 1429.28 & $107.63 * *$ & $1321.60 * *$ & 1039.85 & 430.65 \\
\hline Total $\times$ environment & 15 & $411.03 * *$ & $1028.10 * *$ & $\mathbf{3 7 . 4 3 *}$ & 922.33* & $933.48 * *$ & $435.63 * *$ \\
\hline$i$ type $\times$ environment & 1 & $240.83^{*}$ & 644.03 & $218.70^{* *}$ & $4662.53 * *$ & $6606.77^{* *}$ & 74.26 \\
\hline$j+l$ type $\times$ environment & 14 & $423.19 * *$ & $1055.53^{* *}$ & 24.49 & 655.18 & $528.24 * *$ & $461.44 * *$ \\
\hline Error & 56 & 45.51 & 190.23 & 16.50 & 409.14 & 104.84 & 37.22 \\
\hline \multicolumn{8}{|l|}{ Additive component } \\
\hline Sums $\left(L_{1 j}+L_{2 j}\right)$ & 14 & 80.28 & $1425.62 * *$ & 21.18 & $\mathbf{3 4 7 . 5 0}$ & $478.33 * *$ & 92.27 \\
\hline Sums $\times$ environment & 14 & $58.59 * *$ & $237.89 * *$ & $10.17^{*}$ & $604.60 * *$ & $121.30^{* *}$ & $51.16 * *$ \\
\hline Error & 56 & 20.10 & 82.00 & 5.26 & 136.70 & 31.39 & 4.61 \\
\hline \multicolumn{8}{|l|}{ Dominance component } \\
\hline Differences $\left(L_{1 j}+L_{2 j}\right)$ & 14 & 25.05 & 217.50 & 13.91* & 137.50 & 93.50* & 60.91 \\
\hline Differences $\times$ environment & 14 & 22.60 & $154.56 *$ & 5.95 & 137.00 & 58.67 & $58.93 * *$ \\
\hline Error & 56 & 14.62 & $\mathbf{7 4 . 1 4}$ & 6.98 & 106.90 & 40.17 & 7.13 \\
\hline Source & df & $\begin{array}{c}\text { Seed } \\
\text { length } \\
\text { (cm) }\end{array}$ & $\begin{array}{c}\begin{array}{c}\text { Seed } \\
\text { breadth } \\
(\mathbf{c m})\end{array} \\
\end{array}$ & $\begin{array}{c}\text { 100-seed } \\
\text { weight } \\
\text { (g) }\end{array}$ & $\begin{array}{c}\text { Pod } \\
\text { yield } \\
(\mathrm{g}) \\
\end{array}$ & $\begin{array}{c}\text { Shelling } \\
\text { outturn } \\
(\%)\end{array}$ & \\
\hline \multicolumn{8}{|l|}{ Epistatic component } \\
\hline Total epistasis & 15 & 127.45 & 78.37 & 569.32 & 3133.36 & 1312.83 & \\
\hline$i$ type epistasis & 1 & 6.27 & 79.33 & $1657.42 * *$ & 21652.59 & 1632.02 & \\
\hline$j+l$ type epistasis & 14 & 136.10 & 78.27 & 491.60 & 1810.55 & 1290.03 & \\
\hline Total $x$ environment & 15 & $250.59 * *$ & $123.85 * *$ & $1098.84 * *$ & $2740.30 * *$ & $954.30 * *$ & \\
\hline$i$ type $\times$ environment & 1 & 1.05 & $92.58 * *$ & 150.08 & $18495.87 * *$ & $2236.03^{* *}$ & \\
\hline$j+l$ type $\times$ environment & 14 & $268.41 * *$ & $126.09 * *$ & $1166.61^{* *}$ & $1614.90 * *$ & $862.75 * *$ & \\
\hline Error & 56 & 9.24 & 3.80 & 93.21 & 408.57 & 222.29 & \\
\hline \multicolumn{8}{|l|}{ Additive component } \\
\hline Sums $\left(L_{1 j}+L_{2 j}\right)$ & 14 & $20.72 * *$ & 3.24 & $315.90 * *$ & 683.00 & 119.52 & \\
\hline Sums $\times$ environment & 14 & 10.05 & $3.76^{*}$ & $\mathbf{7 2 . 8 4} *$ & $937.00^{* *}$ & 110.67 & \\
\hline Error & 56 & 5.49 & 1.72 & 33.35 & 160.40 & 78.41 & \\
\hline \multicolumn{8}{|l|}{ Dominant component } \\
\hline Differences $\left(L_{1 j}+L_{2 j}\right)$ & 14 & 8.71 & 2.36 & 180.83 & 133.80 & 50.82 & \\
\hline Differences $\times$ environment & 14 & 7.88 & 1.77 & $126.99 * *$ & 141.50 & 121.12* & \\
\hline Error & 56 & 5.34 & 1.66 & 43.92 & 119.90 & 56.37 & \\
\hline
\end{tabular}

*,** Significant at 0.05 and 0.01 percent levels of probability, respectively.

(Table 4). Therefore, the additive variance was estimated environment wise and only for those traits (canopy breadth and shelling outturn in post-rainy environment and number of primary branches in rainy environment) for which epistasis was not detected either by an $\mathrm{F}$ or a $t$ test (Table 5).

The mean squares due to differences were significant for two traits (100-seed weight and shelling outturn) in the 1992-1993 post-rainy and for four traits (canopy breadth, pod length, pod breadth, and 100-seed weight)

Table 5. Estimates of additive $(D)$ and dominance $\left(H_{1}\right)$ components of variance for traits not showing significant epistasis within the 1992-1993 post-rainy (PR) or 1993 rainy (R) environments.

\begin{tabular}{|c|c|c|c|c|}
\hline \multirow[b]{2}{*}{ Trait } & \multicolumn{2}{|c|}{ PR 1992/93 } & \multicolumn{2}{|c|}{ R 1993} \\
\hline & D & $\mathbf{H}_{1}$ & D & $\mathbf{H}_{\mathbf{l}}$ \\
\hline $\begin{array}{l}\text { Canopy } \\
\text { breadth } \\
\text { Number of }\end{array}$ & $613.21 * *$ & 26.21 & $-\dagger$ & - \\
\hline $\begin{array}{c}\text { primary } \\
\text { branches } \\
\text { Shelling }\end{array}$ & - & - & 1.29 & 2.63 \\
\hline outturn & $71.88 * *$ & 70.48* & - & - \\
\hline
\end{tabular}

*,** Significant at 0.05 and 0.01 levels of probability, respectively, as detected by $F$ test between mean squares due to sums or differences and the corresponding error terms.

$\dagger=$ Not estimated as the epistasis estimates were significant. in the 1993 rainy environment (Table 2). The differences $\times$ environment interactions were significant for canopy breadth, pod breadth, 100 -seed weight, and shelling outturn (Table 4). But, as in the case of sums, the epistasis was also detected for some of these traits (Tables 2 and 3). The dominance variance was, therefore, estimated for only canopy breadth and shelling outturn in the 1992-1993 post-rainy and for primary branches in the 1993 rainy environment (Table 5). Only additive variance was significant for canopy breadth in the 1992-1993 post-rainy environment, and both additive and dominance variances were significant for shelling outturn in the 1992-1993 post-rainy environment. The average degree of dominance $\left[\left(H_{1} / D\right)^{1 / 2}\right]$ indicated that dominance was almost complete for shelling outturn $(0.99)$ and partial for canopy breadth $(0.26)$. The correlations between sums and differences $\left(r_{s, d}\right)$ were significant and positive for number of primary branches $\left(0.59^{*}\right)$ and seed length $\left(0.53^{*}\right)$ and significant and negative for pod breadth $\left(-0.58^{*}\right)$, indicating that the dominant genes have decreasing effects on the first two traits and increasing effects on the last trait.

These estimates of additive and dominance variances were free from the influence of epistasis. However, they may be biased due to linkage relationships. If $\mathrm{L}_{1}$ and $\mathrm{L}_{2}$ are extremely high and extremely low for a trait, both 
additive and dominance variances would be affected to the same extent for that trait and, therefore, the linkage aspect can be ignored in determining the relationship of additive and dominance variances (Ketata et al., 1976). Further, the dominance variance estimated by this procedure refers to loci which differ between the two testers (Mather and Jinks, 1971). If the number of those loci is less than that of all loci segregating in the population for that trait, the dominance variance component is underestimated. Nevertheless, the significance of the differences mean squares indicates that dominant gene action is involved in the inheritance of a given trait. Also, under the same conditions, the additive variance component includes a portion due to dominance deviations and is thus biased upward (Mather and Jinks, 1971). Therefore, only under situations when the mean squares due to differences are nonsignificant, which indicates absence of dominance variance, will the variance due to sums provide the estimate of total additive variance free of dominance contamination regardless of number of loci for which $\mathrm{L}_{1}$ and $\mathrm{L}_{2}$ are different.

It has been suggested (Kearsey and Jinks, 1968) that to obtain more realistic estimates of components of genetic variance, the testers $\mathrm{L}_{1}$ and $\mathrm{L}_{2}$ should be extremely high vs low for a trait under consideration. This, however, is not easy to achieve, particularly when many characters are considered together. Hence, the studies like the present one should be regarded as a means of understanding the types of genetic systems involved, rather than obtaining unbiased estimates of additive and dominance variations.

The results of the present study have implications on breeding and selection procedures in peanut. In cases where $i$ type epistasis is detected, these procedures should be modified to exploit this epistasis. This includes selection in later generations and maintenance of large populations prior to selection to provide the maximum opportunity for advantageous combinations of genes to occur. Selection based on early generation testing would be ineffective. The maintenance of large populations could be particularly necessary when exotic germplasms are used in the breeding program, since the number of possible homozygous genotypes in a segregating population is a geometric function of the number of segregating loci and in the adapted $\times$ exotic crosses the number of segregating loci is expected to be more (Isleib et al., 1978). Lastly, in studies like this which involve the adapted $\times$ exotic crosses it is advantageous to backcross one or more times with the recurrent parent prior to initiating selection in the population to enhance the probability of obtaining the superior lines (Dudley, 1982).

\section{REFERENCES}

Bailey, W.K., and R.O. Hammons. 1975. Registration of Chico peanut germplasm. Crop Sci. 15:105.

Burton, G.W. 1968. Epistasis in pearl millet forage yields. Crop Sci. 8:365-368.

Dudley, J.W. 1982. Theory of transfer of alleles. Crop sci. 22:631-637

Gamble, E.E. 1962. Gene effects in corn Zea mays L. III. Relative stability of the gene effects in different environments. Can. J. Pl. Sci. 42:626-634.

Halward, T.M., and J.C. Wynne. 1991. Generation means analysis for productivity in two diverse peanut crosses. Theor. Appl. Gent. 82:784-792.

Hammons, R.O. 1973. Genetics of Arachis hypogaea, pp. 135-173. In C.T. Wilson (ed.) Peanuts-culture and uses. American Peanut Research and Education Assoc., Stillwater, OK.

Isleib, T.G., J.C. Wynne, and J.O. Rawlings. 1978. Estimates of epistasis for diverse peanut cultivars. Peanut Sci. 5:106-108.

Jinks, J.L. and J.M. Perkins. 1970. A general method for the detection of additive, dominance and epistatic components of variation. III. $F_{2}$ and backcross populations. Heredity 25:419-429.

Jinks, J.L., J.M. Perkins, and E.L. Breese. 1969. A general method of detecting additive, dominance and epistatic variation for metrical traits. II. Application to inbred lines. Heredity 24:45-57.

Kearsey, M.J., and J.L. Jinks. 1968. A general method of detecting additive, dominance and epistatic variation for metrical traits. I. Theory. Heredity 23:403-409.

Ketata, H., E.L. Smith, L.H. Edwards, and R.W. McNew. 1976. Detection of epistasis, additive and dominance variation in winter wheat (Triticum aestivum L. em Thell.). Crop Sci 16:1-4.

Malhotra, R.S., and K.B. Singh. 1989. Detection of epistasis in Chickpea. Euphytica 40:169-172.

Mather, K., and J.L. Jinks. 1971. Biometrical Genetics. 2nd ed. Chapman and Hall Ltd., London.

Nigam, S.N., S.L. Dwivedi, Y.L.C. Rao, and R.W. Gibbons. 1992. Registration of ICGV 87121 peanut germplasm. Crop Sci. 32: 1078-1079.

Parker, R.C., J.C. Wynne, and D.A. Emery. 1970. Combining ability estimates in Arachis hypogaea L. I. $\mathrm{F}_{1}$ seedling responses in a controlled environment. Crop Sci. 10:429-432.

Perkins, J.M., and J.L. Jinks. 1971. Analysis of genotype $\times$ environment interaction in triple test cross data. Heredity 26:203-209.

Sandhu, B.S., and A.S. Khera. 1976. The role of epistasis in the inheritance of yield and its components in groundnut. Crop Improv. 3:9-17.

Upadhyaya, H.D., K. Gopal, H.L. Nadaf, and S. Vijayakumar. 1992. Combining ability studies for yield and its components in groundnut. Indian J, Genet. 52:1-6.

Wynne, J.C. 1976. Evaluation of early generation testing in peanuts. Peanut Sci. 3:62-66.

Wynne, J.C., D.A. Emery, and P.W. Rice. 1970. Combining ability estimates in Arachis hypogaea L. II. Field performance of $F_{1}$ hybrids. Crop Sci. 10:713-715.

Yermanos, D.M., and R.W. Allard. 1961. The detection of epistatic gene action in flax. Crop Sci. 1:307-310. 